\title{
e-Migrinter
}

$8 \mid 2012$

Regards sur les migrations sud-asiatiques

\section{Transnational masculinity: Indian nurses' husbands in Ireland}

\section{Marie Percot}

\section{(2) OpenEdition}

1 Journals

\section{Édition électronique}

URL : https://journals.openedition.org/e-migrinter/630

DOI : $10.4000 /$ e-migrinter.630

ISSN : 1961-9685

Éditeur

UMR 7301 - Migrinter

\section{Édition imprimée}

Date de publication : 4 avril 2012

Pagination : 74-86

ISSN : 1961-9685

\section{Référence électronique}

Marie Percot, "Transnational masculinity: Indian nurses' husbands in Ireland », e-Migrinter [En ligne], 8 | 2012, mis en ligne le , consulté le 20 mai 2021. URL : http://journals.openedition.org/e-migrinter/ 630 ; DOI : https://doi.org/10.4000/e-migrinter.630 


\section{Transnational masculinity: Indian nurses' husbands in Ireland*}

Marie Percot

\section{I} have met many young Christian men ${ }^{1}$ in Kerala whose ambition, like Philip's, was to migrate by marrying a nurse. If the matrimonial market used to be harsh on nurses a few decades ago, the picture has changed and nurses are now on high demand. The stigma attached to this profession in India has certainly not completely vanished, but in Kerala, nursing has become a real chance to enhance one's career opportunities. While visiting matrimonial websites, ${ }^{2}$ it is easy to check how much they are looked after by prospective grooms.

However despised may the commonly named USA nurses be by the highest class/casts (George, 2005), they tend to represent the key to the Western dream for loads of young men belonging to the Christian Malayali ${ }^{3}$ middle class who don't envisage the possibility of a bright future in their own country.

\footnotetext{
*I wish to thank Aurélie Varrel for her valuable comments and Laurence Renn for her careful reading of the last version of this paper.

14/5 of Indian nurses are Malayali and more than 4/5 of Malayali nurses are Christian (for details on this regional and religious "specialisation"; see Percot, 2005).

${ }^{2}$ See for instance keralamatrimonials.com, keralamatrimony.com or shaadi.com.

${ }^{3}$ People from Kerala are called Malayali (their language is Malayalam).
}

On a nice Sunday afternoon in Kerala, Philip", Asha and I were cruising the backwaters from Kottayam to Allepey on a house boat. Asha, a 27 year old Hindu nurse, had just come back from Saudi Arabia, where she had been on a work contract. Philip, a 26 year old Christian man, had remained unemployed ever since he had graduated from a Master's programme in Social Sciences from Trivandrum's Centre for Development Studies. As be had not much to do, he had accepted to help me tour the area for my interviews. Both of them were unmarried. Asha, who had already told me how her own wedding had been postponed several times because of her father's debts, was the one to start the discussion on marriage, asking Philip what his plans were; Philip answered that he wanted to marry a nurse working in the UK. She teased him, asking directly: "How much will you ask for the dowry, you who don't even have a proper job here?". She obviously wanted me to bear that he was nevertheless expecting a pretty good dowry and was considering himself as a potential good match for a migrant nurse since be was "bighly educated" and "already speaking a very good English". He was quite sure that this would help him in his future career as a migrant worker. Asha, a bit revolted by what she had just heard, concluded: "He will get his UK nurse, you will see!". Three years later, I happened to get some news from Philip, who had indeed married a nurse named Pax, and who was asking me if I could send a recommendation letter to belp bim get a job. Ever since that time, I receive mails and pictures from time to time (featuring their daughter, their apartment, or even his mother visiting them in the UK), but it is rather difficult to get detailed information about what he is doing precisely. His explanations are rather vague, such as: "I have been working in a restaurant", "I am expecting a good opportunity" or "I have worked in the same hospital as Pax this past month"... Lately, his wife has been the one answering my mails. Definitely, his

${ }^{4}$ All the names have been changed. 
"career" is not what he was dreaming of before leaving Kerala.

In the 80's and 90's, the main destination for Malayali nurses was the Persian Gulf. Nowadays, more and more of them migrate to the West (USA, UK, Australia, Canada...). Western countries recruit health workers for a limited amount of time according to their needs, and stop recruiting whenever their needs lessen. Most of the nurses in Kerala keep themselves informed of the tendencies of this recruitment policy, and are therefore aware of the possible destinations for migration at all times. Ireland, which for almost a century used to send many female nurses to the USA principally (Yeates, 2009), was a recruiting country from 2000 to $2008^{5}$. A few thousands of Malayali nurses reached Ireland to work in the country's hospitals ${ }^{6}$, being the first representatives of this community on Irish lands. Some of them were already married; some of them got married once they had migrated. Since the migration laws allowed family reunification, husbands and children were soon to follow.

In 2009, I stayed three weeks with a Malayali family in Dublin. As the wife Reena was a nurse, I spent most of my time there with Mathew, the husband of the family, and their two children. Of course, Mathew took me to several touristic places but we also visited a lot of his Malayali friends, all of whom, just like him, had married nurses. A few dinners were organized, along with a tour by the sea with a couple of other families. This paper is based on this fieldwork, the first one I conducted in a Western country, after conducting a research on Malayali nurses in India and in the Gulf throughout the 2000 decade (Percot, 2006; Percot \& Naïr, 2010).

\footnotetext{
${ }^{5}$ After 2008, which marks the beginning of the economic crisis in Ireland, the recruitment of foreign nurses has stopped in this country.

${ }^{6}$ Estimates give 2.000 foreign nurses recruited per year in Ireland between 2000 and 2006. 40\% of them are Indian (Humphries, 2008).
}

\section{Marrying a nurse in order to leave from Kerala}

Kerala, a South Indian state, is famous for its model of development (Jeffrey, 1993). The literacy rate and life expectancy are for instance the highest in India while fertility rate is the lowest ${ }^{7}$. Yet, economic development did not follow the same good lines and unemployment is a major problem, particularly striking young people with higher education. Since the 60's, many Malayalis have migrated to the metropolises of India and from the 70's onwards, many of them have left for the Persian Gulf. Today, among the officially reported 4 million Indian workers in the Gulf, half of them are from Kerala (Zachariah \& Rajan, 2004). Malayali nurses, who represent $80 \%$ of the Indian nurses, are part of this broader phenomenon of migration.

In Kerala, parents invest a lot in the education of their children, especially boys. Many children attend an English medium school and pursue higher education. However, because the investment needed is too high for the parents to handle, or because the child does not prove to be a brilliant enough student, a lot of children stop their studies after obtaining a diploma in computer science or tourism, but such diploma is not valued highly enough on the work market, and it is difficult for them to find a job. Even in the case when the students earn a more prestigious degree, be it in law or social sciences for instance, it is not very much more useful while they find themselves in search of a job in the sluggish economic context of Kerala. Young men are then left with nothing to do, feeling trapped in the middle of nowhere, with no financial independence and no way of getting married and start a family (Osella \& Osella, 2006; Nisbett, 2009). Hanging around with mates

\footnotetext{
${ }^{7}$ Literacy rate in Kerala is $93,91 \%$ compared to 74,04 $\%$ for India (Census, 2011); fertility rate in Kerala is 1,7 children per woman (Census, 2011). Life expectancy in Kerala reaches 68,8 years for men and 74,4 for women (Census, 2001).
} 
who find themselves in the same situation, spending a lot of time dreaming of a better life, they consider migration as a solution to most of their difficulties. For migration is not only a means of making money; it has also become a real culture. Although it can originate from economic necessity, it is also a way of life. To quote Kander and Massey (2002 : 982), "as migratory behavior extends throughout a community, it increasingly enters the calculus of conscious choice and eventually becomes normative" ${ }^{\text {. In Kerala, }}$ most families account amongst their members somebody working abroad. For the young men especially, going abroad - at least for a few years - is part of a man's experience, a sort of "rite de passage" to real manhood, as it has also been observed in other societies where migration is a common trend ${ }^{9}$. It is particularly true for many young men of the middle class or lower middle class. For the young generation at least, a successful man is defined and described as a "cosmopolitan" one: i.e., from an emic point of view, a man who has found the way to travel abroad, to see more than the rather provincial Kerala, who has had an access to the most "modern" metropolises of the world. Migration is also a way to take some distance with a society whose traditional norms and strict social control can be a little bit hard to bear for its youngsters.

Yet it is not so easy to leave because it requires both investment and a good network. The Gulf is surely the easiest and the cheapest option because trip and contract prices are less for this destination and it is possible to find job offers even for those people with very low qualifications. But most prized - with the exception of Dubai perhaps - is the West where only 11\% of Malayali migrants are currently settled (Zachariah \& Rajan, 2008). Migrating to the West is a possibility for those with a degree in medicine or in engineering, because Western countries have special migration

${ }^{8} \mathrm{On}$ this question of migration tradition, see also Mines, 1981.

'See for instance, Monsutti, 2005 or Boehm, 2004. policies for such people; but it remains largely out of reach for those with the type of training most young men have (technical training, tourism or computer science diplomas...). When you are a Christian, marrying a nurse is the best option to achieve this goal.

For a nurse, migration has become the normal path. Indeed, one becomes a nurse today in Kerala in order to migrate: during my last survey in Kerala's and Delhi's nursing schools in 2009, almost all of the 350 nursing students surveyed were planning to go abroad... The youngest generation of nurses leaves as soon as possible (after two years of professional experience ${ }^{10}$, before getting married ${ }^{11}$. This is considered as the best strategy since, on the one hand, the possibility of emigration that they may offer to their future husband will play a role in the negotiation of the dowry amount that their parents will have to pay; ${ }^{12}$ and on the other hand, it is also for these young women the best way to make sure that their career plans will not be endangered by future in-laws (some families may not like the idea that their son's wife is working abroad and could stop such a move if the nurse is not already a migrant at the time of the wedding). A nurse working in the Gulf will be able to get a visiting visa for her husband quite easily; he can then find a job contract on the spot. In a Western country, it is even simpler due to the immigration laws allowing family reunification: for many young men, that is the door open to most of their dreams.

\footnotetext{
${ }^{10}$ This is the minimum time of experience required by the foreign hospitals in the Gulf as well as in the West.

${ }^{11}$ Until the 90's, migrant nurses were generally older and married: as long as the conditions of living in the Gulf were unknown (but also the actual financial advantages), it used to look too adventurous for a young single woman to leave alone (and parents would have been badly considered to let an unmarried daughter doing such a choice).

${ }^{12}$ In India, the dowry is paid by the woman's family. Dowry was officially abolished by law in 1961, but it is still a very living tradition, especially in Kerala where dowries reach records partly due to migrants' remittances.
} 


\section{"Behind every successful man, there is a woman": a painful cliché}

In Kerala, the image of these men "following their wife" is not a very positive one. Nurses' husbands - a well known stereotype - appear as a real challenge to the traditional representation of masculinity. They are commonly mocked in novels, films or newspapers as emasculated and not in a position to fulfil the normal men's tasks. As they are generally the best earners of the family, their wives are supposed to have a full control on them, reversing the "normal" role. This extract of an article in Gulf Times most probably written by a Malayali journalist considering her name- expresses what is well known and looked upon rather disparagingly in the country: "Malayali nurses $[\ldots]$ have led their families to far away Europe and most today are the sole bread earners with their men content to play house-husband. One could just twist the adage 'Behind every successful man, there is a woman' - to read - 'There is a nurse behind the success and prosperity of each family' to suit the European Malayalis"13.

Yet, these clichés and prejudices do not prevent young men (and their families) from choosing this option. In fact, reality is ambiguous. Rather despised in the common discourse, nurses' husbands have nevertheless an access to a way of life which is largely coveted, particularly by the young generation. They travel, they come back home with lots of goods, wear branded clothes. They have the possibility to be generous with their friends, treating them in restaurants or bars, paying for cinema, and so on. At least during their first years of migration after marriage, they appear, compared to their still unemployed and often still single friends ${ }^{14}$, as quite successful men who are already engaged in "the real life". That marrying a nurse can also be an

${ }^{13} \mathrm{Liz}$ Mathew, "Malayali nurses - lifeline of Keralites abroad" in Gulf Times, 26/09/06.

${ }^{14} \mathrm{On}$ the different traditional stages of manhood in Kerala, see Osella \& Osella, 2006. enviable situation is, for instance, illustrated by the following anecdote. While travelling in a taxi, the driver - a Christian man explained to me that he had done a "love marriage" with a Hindu woman despite his family's displeasure. To highlight the strength of his love, he argued that he had married his wife although he had even been proposed a USA nurse coming with an Ambassador [an Indian car as part of the dowry].

Marrying a migrant nurse therefore appears as a sort of compromise between the traditional gender role according to which a man should be the one who leads the family and more modern aspirations which would otherwise be inaccessible. However, few young men have a very realistic appreciation of their chances concerning jobs in a Western country since it is still not a traditional path of migration for people belonging to their social class. Until now Malayalis - and Malayali nurses as well - have mostly migrated to the Persian Gulf. For the previous generation of nurses' husbands, getting an occupation in the Gulf has been pretty easy since most of them had a technical background as plumbers, mechanics, carpenters, etc. Although their wages tended to be generally less than their wives', they were not so bad either. But the new generation of nurses' husbands have a different curriculum because nurses' families are no longer willing to "give away" their daughters to blue collars and prefer more "prestigious" sons-in-law. The strong Malayali community, which is nowadays settled in most places in the Persian Gulf, is of great help for these newcomers who are recruited as white collars by the many service companies managed by compatriots, even when they do not have very specific qualifications. Thus in the Gulf, all nurses' husbands do have an occupation, all the more so that it is not possible to stay in these countries without having a job contract.

For those husbands who followed their wives to the Gulf, traditional gender 
roles have not been so much shaken up. Both members of the couple work - as it is now frequently the case in Kerala itself ${ }^{15}$. Migrant nurses underline the fact that they have more say in the economic decisions of the couple, something they judge very positive (Percot, 2006). They see it as a consequence of their good wages but also of living as a nuclear family with no parents around to influence their husband too much. Husbands are themselves prompt to acknowledge the benefits of the nuclear family, arguing that it is a more "modern" family pattern and that it gives way to better chances of personal and economic success: At home, everybody bas sometbing to ask you and it is difficult to resist. Here, we have more distance, we can think about our future and the future of our children. We discuss it together [i.e. with his wife] and we make plans. When you live abroad, you know the value of savings and you have to make plans, explained for instance Beejee who had been living in Oman for five years before the couple emigrated to Ireland in 2008.

The majority of migrant Malayali nurses work in the Gulf and the majority of those who are currently working in a Western country have spent some time in the Gulf itself in a process of step by step migration that initially took place in India by moving from Kerala to a big Indian metropolis (Percot \& Nair, 2010). The West is generally considered a better place for many reasons. Religious background does not seem to play a role ("Muslim" countries versus traditionally "Christian" countries) ${ }^{16}$, neither does modernity which is no serious argument since Dubai for instance can be

\footnotetext{
${ }^{15}$ The difference for the women is that they have to take care themselves of the domestic tasks without the help of a maid as it is generally the case in Kerala for people of this social milieu. In addition, because it would be too expensive to pay for a caregiver in the Gulf, children are most often left behind in Kerala to the care of in-laws.

${ }^{16}$ Except for Saudi Arabia where there is no religious freedom, Christian Malayalis have their own churches and religious associations in all other Gulf countries. None of my informants ever mentioned preferring the West because it is a destination of Christian tradition.
}

seen as the pinnacle of modernity. Two aspects practically do make the West more appealing: first, the possibility of family reunification and the public school system which make it easier for families to take their children along when they migrate; then, the possibility to obtain another citizenship: i.e. a passport promotes the freedom to travel everywhere and even to settle in a lot of countries, something they could not achieve with an Indian passport ${ }^{17}$. The symbolic benefits of getting another citizenship (or more concretely another passport) are also very important; it is the key to achieve the highly valued status of a cosmopolitan. And it is something which cannot be achieved in the Gulf. As Thomas, who was about to leave Kerala for Abu Dhabi where his wife was working, put it: You can't spend too much time there [...] There is no way you can settle. You can't even buy a house; you will never get a passport. That is just to make money, not a future ${ }^{18}$. So, even when their situation is good in the Persian Gulf, it seems that a lot of nurses' husbands encourage their wives to apply for a job somewhere in a Western country.

Reaching the West is for sure considered as a sort of achievement in itself and those who have been able to do so do their best to show this success to their family and peers at home. From the host country, through such social networks as Facebook, migrant men display lots of pictures showing themselves in their new environment (pictures of the house with furniture, computers, TV, etc.; pictures at the wheel of the new car; picture of the tourist tours made in the new country, etc.); while on holidays in Kerala, they seize many occasions to show that they can spend more

\footnotetext{
${ }^{17}$ Indeed, many Indians complain that the world meaning especially the Western world - has become for them a real fortress. This situation is often reminded as an injustice to the Westerners visiting India.

${ }^{18}$ One should note here, that in the Gulf, some Malayali entrepreneurs are achieving an economic success large enough to counterbalance the impossibility of getting another citizenship (see Venier, 2011).
} 
than their local compatriots, as all migrants do. But, unlike the Gulf migrants, they have an experience to tell about countries that most Malayalis are very curious about. However, when discussing with them, it is difficult to have a clear picture of their occupation in their host country. All the 26 nurse's husbands I have met in Kerala and who were settled in a Western country (UK, Australia, Switzerland and Ireland) introduced themselves as "being in business". Only two were more specific: a man living in Zurich was managing a travel agency working mostly with Sri Lankan Tamil refugees; the second one, settled in UK, was employed as an accountant by an Indian spice company.

\section{Business men or house-husbands? A challenge to traditional masculinity}

Most men have indeed no specific idea about what kind of career they will be able to pursue upon arrival in a Western country. When I asked Mathew, as he was about to leave for Dublin, in which field he intended to work there, he answered that he was sure that the experience that he had acquired in the field of tourism while he was working in Dubai would be very valuable. ${ }^{19} \mathrm{He}$ had been the one to urge Reena to apply for this country, although she was also rather excited at the idea of reaching Europe (to be in Europe where real things happen and because she had high expectations concerning the professional level, altogether because of the hospital standards and because of possibilities of specialisation in nursing). Anyway, the move had to come from Reena since the departure to the West was depending on her ability to "sell" herself on the international nursing job market.

Following their wives, stricto sensu, for nurses are always the first ones to arrive in

\footnotetext{
${ }^{19}$ In Dubai, he had worked three years at the airport desk of a car rental company whose director's family was his neighbor in Kerala.
}

the new host country, the men I have met are nevertheless confident in their chances to succeed by themselves once they reach the destination. In that aspect, they are not so different from their counterparts who are still only planning to marry a nurse with no further plan. The position of "follower" is not denied but minimized as if it had no more incidence than a "way to enter": $O f$ course, that is Teresa who entered first. That is because of the immigration law. But both of us have a working permit now, that is the main thing commented Joseph, a 32 year old man living in Kilkenny. However, though he had been there for more than a year, he was unemployed when I visited his house: after having tried many low-wage jobs (pizza delivery, distribution of flyers, etc.), he was now taking care of his two young children.

Nowadays, most migrant nurses are rather young women ${ }^{20}$, hence those children who are implied in the migration process today are often toddlers or babies. Children move along with the husband in the case that the latter remained in Kerala; a little bit after the husband when the couple used to work in the Gulf and thus had left the children in Kerala. But, in Ireland, there are almost no crèches and the cost of child care by a private assistant is high. The couple has thus to manage by itself according to the working schedules of both parents. Since nurses are the ones to have a proper contract and a rather good salary ${ }^{21}$, husbands have to adjust their potential working time according to their wife's schedule. The whole organization is made even more complicated by the fact that a nurse's duty is always changing: on the one week she will

\footnotetext{
${ }^{20}$ Because of the time necessary to get a nursing diploma, of the two years of experience required before migrating and, at last, of the minimum of time needed to save some money for their dowry, nurses get married comparatively later than their compatriots. The nurses I have met in Ireland where aged between 28 and 37. All of them had at least one child and maximum two children. All the children were below 10 years old.

${ }^{21}$ The women I met in Ireland earned between 2000 and $3000 € /$ month.
} 
have night and/or week-end duty, while on the following week, she will have to work during day time. If men had a chance to get a good salary, they would for sure prefer to hire someone to take care of their children. But what they get are generally minimum wages, and often not even on a regular basis, so that many of them (almost all of the men I met) end up as reluctant house-husbands at least during the time that their children are not old enough to attend school.

This is not a man's job, explained Mathew, but what is the point of paying a woman you don't even know? We are more modern than our parents and we know the value of money [...] By the time Rosy [their 2 year old daughter] gets old enough to go to school, I will be able to get a licence to start a travel agency. For the time being, I am expanding my network. I have good contacts at home and in Europe. You have to be patient sometimes! The "modernity" displayed by Mathew had nevertheless a limitation which almost seems to be a norm: Rosy had been left to the care of his parents in Kerala until she had reached the age of 15 months. Mathew as well as his wife, Reena, both agree on the fact that a man cannot take care of an infant properly. Nevertheless, as I was able to observe, Mathew had indeed learned to feed his daughter, change her diapers or give her a bath, and was perfectly able to take care of his 6 year-old son John at the same time; he had developed a good organisation with both children as well as with all the domestic chores (contrarily to my assumption based upon what I had observed in Kerala or in the Gulf, he was really taking care of everything and Reena had not so much to do when she came back from work). ${ }^{22}$ The couple is buying a house in the suburb of Dublin, in a place where the neighbours are mainly Irish. Mathew has made friends with some of them and they have organised turns to drop or pick up the children from school. He insisted on the nice relations he has been

\footnotetext{
${ }^{22}$ Mathew and Reena are the only family with whom I have been staying in Ireland. Their case could be an exception and it is of course not possible to draw of any general conclusion from this example.
}

able to establish with the locals, thanks to the children's presence and to the Catholic parish of which they are members. A well furnished house in Ireland, a good car, a child already attending a Christian school and speaking fluent English, a house being built in a tourist station in Kerala, all together constitute the main symbols of success. In addition, Reena has been able to complete a degree of specialisation at the same time as she worked at the hospital (her photo in her graduate gown welcomes the visitors in their house entrance). But, if Mathew insisted on how proud he is of his wife, his own "postponed" career is difficult to stand for him. During my stay, the couple has had several altercations, with Mathew asserting that life is easy for Reena and that he was the one to do everything. The discussion generally started with a detail concerning the children's education. For example, we went to the restaurant once, and Reena was trying to feed Rosy who was refusing everything. Mathew seized the spoon from Reena's hand in a rather violent movement and started to force the food into Rosy's mouth, to no avail. As she mocked him on his poor result, adding that as a woman and a nurse, she perfectly knew how to behave with a child, he retorted that her knowledge was purely theoretical and that she was not superior to him in that respect, concluding that as long as it is my responsibility, I am the one in charge. $\mathrm{He}$ then left the restaurant with a crying Rosy. Coming back on the discussion some hours later, he explained to me that the situation was sometimes driving him crazy: That is not normal for a man to spend all the time alone with the children. There are days where I do not speak to anybody. I am at home, worrying on my future. I don't think there are good opportunities for men in Ireland.

Paraphrasing Gallo's paper about Malayali men in Italy (Gallo, 2006), I could say that Ireland "is not a good country for men" either, for all the men I have met there were more or less in the same situation as Mathew. Moreover, the economic crisis which sternly hit Ireland has also worsened 
the situation. All of them were trapped into alternating petty jobs from a few days to a few months and times when they were just taking care of the children. Ten of them had obtained a job in the hospital where their wife was working, but seven of them soon resigned because it was really too painful for them to be seen working in an inferior position. As stated by Thomas: It is not possible to be in a position where your wife can be giving you orders because she is a nurse and you are a nobody. You know how it is in Kerala, that is not the way. One of his friends added that it was not normal for men "in general", for no Irish nurse's husband was working under his wife either. Thomas and his counterparts had been expecting white-collar jobs upon their arrival in Ireland, but they quickly had to realise that it would not really be possible. Malayalis are newcomers there; the community is a rather small one still and has only been enlarged by the recruitment of nurses. No Malayali business exists until now which could hire these men as it is usual in the Persian Gulf: a fact that none of them seems to have anticipated. It appears that only once landed in Ireland did they understand the difficulties of being pioneers. The working network of their wives is the only one to be possibly used and it is not satisfactory, economically but above all symbolically. Once again, these men are trapped in a situation where they feel that their real future is still to come.

When I was in Ireland in 2009, most of the 17 men with whom I had the time to discuss had given up the idea of finding a proper job as an employee. Most of them were intending to open a business as soon as their stay had reached a sufficient amount of time in order to get a licence and the minimum of saving to invest and/or to apply for a loan. Their projects were either an Indian restaurant or a travel agency specialised in trips to India. When they were present during our discussions, their respective wives were rather encouraging, highlighting what their husbands had already been able to achieve: In Abu Dhabi, he has managed the canteen of a big company. He has acquired experience and here it is just a question of a small restaurant to start with" or "His cousin is running a travel agency in Kottayam. He was the one to invest and to put his cousin as a manager ${ }^{23}$ [...] Many Irish people travel to India and there are not many travel agents specialized in tourist tours of India. This is his dream to open his agency here. He is already visiting shops to rent, even if he still has one year to go before he possibly gets a licence. I do not have enough data to say whether their plans were realistic or not - or even if it was not just a sort of ritual discussion for these men as soon as they were together-, but they had good examples to give me of friends who had successfully done so in the UK or other Western countries. However, none of my informants has come to know of a business opened by a nurse's husband in Ireland until now. None of my informants either had a background in entrepreneurship in the family ${ }^{24}$. Indeed, some of the men I met were a little bit pessimistic about their actual chance to achieve such a project of business and the tendency was to imagine a new step in migration: Australia, the new country recruiting a lot of foreign nurses, was now appearing as offering better opportunities than Ireland, at least for the men.

However, leaving again may not be so easy. First of all, many couples have bought a house in Ireland and are now stuck with heavy loans to reimburse at a moment when the real estate market is catastrophic: selling the house is almost impossible. Then, many nurses - even if they agree that the overall situation is really bad nowadays in Ireland ${ }^{25}$ -

\footnotetext{
${ }^{23}$ John did not present himself as "co-manager" of this business.

${ }^{24}$ One may point out here that those who have this background -or who have been able to take this pathhave been sometimes very successful in the Gulf, even if they had at first to "use" the opportunity of migrating through their nurse wife.

${ }^{25} \mathrm{My}$ last discussions on the phone or through mails with Malayali nurses in Ireland show how they worry about the situation. All of them had cut on their salaries and some of them are afraid that their contract could be terminated.
} 
really appreciate their job and working conditions compared to what they have experienced in India and even in the Gulf, be it from the doctors or from the patients side. Thirdly, these women argue that their children are very well integrated once they have started going to school and that it will not be good for them to move. ${ }^{26}$ At last, most of these migrant couples are engaged in a process of naturalisation: leaving before getting the "European passport" 27 appears as a waste. This last argument is largely used by the women who would rather stay in Ireland.

\section{Socializing: a major occupation for men}

The roles of men in Ireland are obviously not those of traditional Malayali men. Though they mostly agree that behaving as "modern" men is not so much a problem - except for their poor professional activity - , nurses' husbands feel nevertheless uncomfortable. As Teresa, a 32 years old nurse, explained: We are no traditional Malayali family anymore. We are a modern family [...]. It is not like it used to be in Kerala where the husband decides for everytbing and the wife just has to say 'yes, yes'. It means that both of us discuss what is good to do, what is good for the children, what we will do in the future [...] Both of us have to take care of everything. MP: Is it because you are earning more or because you are abroad? A. : We [nurses] are the main bread-earners. But the main thing is that we [as a couple] are on our own here. Nobody is around to tell you what to do, what to think, or to gossip around. Her friend Teresa however added: But you bave to take care of the pride of

\footnotetext{
${ }^{26}$ That children are able to speak a little bit of Gaelic in addition to English has been often emphasizes by the nurses I have met as a sign that they were now "real Irish".

${ }^{27}$ The idea is not so much there to "become Irish", but pragmatically to get a passport with which they can travel easily without having to ask each time for visas; visas which are moreover often denied to Indian passport holders. Any Western passport gives this facility, that is why my informants speak of "European passport" (meaning a passport from a Schengen space country).
}

your husband. It is not so easy for them bere. They are not used to do such things as taking care of children, cooking [...] You bave to be careful not to burt their pride. MP: What does it mean practically?. T.: You don't try to play it smart in front of other people. For instance, when you do not agree, you wait to be alone to discuss. He should not be ashamed in front of his friends.

Men try thus to find some space to reassert their masculinity. Sheba George in her study about Indian nurses in USA (George, 2005) argues that men do so through religious activities and religious associations in which women have almost no space. But in Ireland, the new and small Malayali community is still not organized enough to create such structures for itself. There is no public space to meet and to do things together. If they are Roman Catholics, they attend the mass at the local church where they may be the only Malayali family. Since a priest was sent two years ago to Dublin, it is now possible for the Syrian Christians to attend a mass according to their rite; but they still do not have a church and the religious activities are restrained because of the scattering of Malayali families on the Irish territory, making it difficult for them to meet on a very regular basis as a community. Consequently Malayalis socialize on a private basis.

Malayali nurses are now found in most big Irish hospitals. This provides a starting point for men if they want to know some of their compatriots: the first network is thus generated by their wives, even if the latter do not meet so much besides their working place. Another network comes from members of the family or neighbors in Kerala who have also migrated to Ireland (in the case the wife is a nurse too). Malayalis in Ireland are keen in knowing the newcomers and at being in touch with them as soon as they arrive. But since women are very busy, socializing is mostly a men's issue.

Being relatively free in the afternoon, men visit each other and spend a couple of 
hours together till it is time for the children's dinner. Besides discussions, it is also an opportunity to take care of the cars, to go shopping or to look around for a house for a newly arrived family. But these visits to friends are constrained by the wives' schedules. For instance, it is not so much possible to visit a friend whose wife is sleeping since she is on night duty; men also prefer not to go to a friend's place if his wife has a day off. To decide which friend(s) to visit means a whole series of phone calls which may end up staying at home alone. Anthony explained: At home [in Kerala], you just drop by any house. Here, people are busy and they may live quite far from you. It is a different way of meeting. You have your children with you; sometimes you have to pick up your wife at her hospital or at the station. So everything has to be organized [...] When everything goes well, you may have a nice week. But imagine that a child is sick or that everybody's wife is on night duty and you are stuck. It can be awfully boring. However men insist on the real friendships they have been able to build in migration, as Mathew put it: We, here, have the same experience. When I meet with Anthony or Thomas, we have plenty to discuss. We share the same problems. There is nothing to bide. They are like brothers to me now. This experience, particularly of the untraditional situation that they have to face, makes it all the more necessary to build collectively a self-image that is possible to bear. As we have seen, it is one of a modern man; it is also one of a man who has still a lot of projects to develop: hence the long time spent to discuss the future business or the next destination where it would be easier to start something professionally. However, these visits also help acknowledge the actual achievements such as the new house, the new car, the new computer, etc. The access to consumer goods definitely plays a significant role in keeping self-confidence.

Another way of gaining some prestige among migrants but also at home, in addition to the pleasure that can be derived from it, comes from tourist trips. Moreover, for these Christian people, tourism can be associated with pilgrimage: the two most praised destinations, Lourdes and Roma (the latter at least for those who are Roman Catholics), are affordable while living in Ireland. Ten families among the people I met in Ireland had already done the trip to Lourdes, four of them to Roma. Mathew and Reena with whom I was staying had even added the near Paris Disneyland to their destinations (large pictures of these visits were on display in the houses of Mathew's and Reena's parents in Kottayam during my last visit). These trips are done on an individual basis. It is a little different for the small tours in Ireland, when two or three families may go together to visit friends or parents living in another town and take this opportunity to visit famous places as well. During such tours, as I have observed, men are back to a more traditional role of leader: they are the ones who organize everything, decide where to stop, what is worth visiting or not, in which restaurant to eat, etc. ${ }^{28}$. They are the ones to take most of the pictures (which are sent almost immediately to India or to friends working in the Gulf) and they are the ones who call Kerala to give details about the trips' progress ${ }^{29}$.

Relations with the home country are also clearly a men's business. It seems that they are always the ones who call, handing the phone over to their wife if they are calling her family. Through mobile phone, Skype or internet, they maintain a constant link with family and friends in Kerala, but also with the migrants they have met in the Persian Gulf, if they used to work there as many did. Phone calls are given on a daily

\footnotetext{
${ }^{28}$ Several times, their wives made discreetly fun of them for these attitudes. But I do not know whether it was due to my presence as a Western woman with supposedly different standards or not.

${ }^{29}$ For instance, as we were on a boat in order to see the famous dolphin of Dingle harbor, Thomas called his uncle in Kottayam for more than 45 min, telling him live each time the dolphin was jumping around the boat; on the same day, he called a friend in Dubai to make him listen the bagpipe band that was playing in a bar where we were drinking a Guiness. (We went to the bar because the men decided that, as a tourist in Ireland, I had to taste the typical beer...).
} 
basis with family at home and are sometimes followed by another session on Skype which is used to show the young children who are not yet able to speak on the phone; it can also be used to show newly bought items. According to my informants, they spend around one hour a day speaking to somebody in India, sometimes more. In the family I was staying with, these conversations reached an average of almost two hours a day. In addition, the men in Ireland have an intense internet activity through emails or different social networks (Facebook, Hi5, Zorpia, etc.) to which they are very often connected. Thomas, for instance, has an account on six different networks; Mathew claims to be connected for more than one hour a day on three of them. New "friends" are regularly added (mostly from Kerala, but also from other countries of migration) and new pictures appear at least every week (pictures of a friends' meeting or pictures of the children are posted when there has been no special occasion such as a trip, a new apartment or house, a car, a visit of a family member coming from Kerala, etc.). Of course, men have obviously more time than their wives to spend in these activities of communication. However, this kind of monopoly allows them to appear as the actual head of the family and to reaffirm their image as successful migrants in their home country. Hence, gender roles are obviously largely shaken up in the everyday life, migrants do their best not to make this reality visible from Kerala at least. On the one hand, the men's "pride" has to be protected; on the other hand, migrants men as well as women - are also careful not to directly challenge the social norms of their home country. Because they indeed mostly subscribe to these norms and/or because they have not succeeded professionally as individuals, men (and consequently their wives) are not in a strong enough position to assert another way of life in front of their non-migrant compatriots.

The extensive use of mobile phones, Skype, emails or connections to social networks on the internet to keep in touch with those stayed at home or with other migrants, corresponds to the image of modern (business)men that nurses' husbands are keen to give. But as a result, these men, more than their really busy wives, live more "here and there" altogether, nurturing a closer link with the country of origin and being more attached to what has to be invested there (a house, a possible business in partnership, family relations...). However, this stronger link with the home country does not seem to give way to a greater nostalgia or to a greater will of return. Part of the time spent in this communication activity, as well as the time spent with friends in Ireland, is used to discuss new opportunities, to look for a place where it will be better for men (but pragmatically a place which recruits nurses, so currently Canada, Australia or NewZealand). To move somewhere else is not seen (or not said) as a sign of a failure, just as a normal step for real cosmopolitan people as they henceforth consider themselves.

\section{Conclusion}

'Like transnational movement itself, gender identities are characterized by fluidity, movement, and transformation", Boehm notes (2004: 20). Ester Gallo remarks that "the construction of masculine identities in the global space emerges as an ambiguous and conflicting process" (Gallo, $2006: 169)$. That undoubtedly is the case for migrant Indian nurses and their husbands. They have to experience a new male/female division of labor which is very different from the traditional one. Yet, this is not, I will argue, so badly accepted or considered by the migrants themselves or within the migrant community. The trouble comes partially from facing the judgment of compatriots: the clichés about these "househusbands", considered as unable to support their family, hurt these men who moreover had expected something else from their migration life. Yet, the main problem is their 
lack of professional achievement. As individuals, they had chosen to "make it" abroad and that is exactly why they had married a nurse. But due to their social, cultural and educational background, they are not prepared to fit the job market in Ireland. In the same way that before their marriage, they had waited for their "real life" to start, they are again trapped with the same feeling after reaching Ireland.

The women, with their qualifications, have a career, which may be brilliant for some of them. Most of the nurses I have met in Ireland are satisfied and even proud of what they have been able to achieve by themselves. The majority enjoys their life and considers that this experience is good for their children. But the frustration of their husbands when it comes to their own career gives a sense of precariousness to the life of all the family members. Moreover, the husbands' dream of a new destination where opportunities would be better for them appears as a threat: to their wives who are on more long term strategies (of climbing the professional ladder, of becoming the owner of a house in Ireland, of getting the citizenship); to the children who - when they are old enough - are well aware that it is from their father's side that they can fear a move far from a place which is the only one they are familiar with.

A new trend has come out these very last years in Kerala that is still to be investigated: some young Christian men are entering the nursing schools in Kerala with the idea of migrating by themselves, without having "to follow [their] wife"; they represent $20 \%$ of the last student batches. They are still to enter on the world job market. But it already shows that it has become possible today to defy the stereotype which defines nursing as a pure womanly occupation. The opportunities of migration attached to this profession have for sure played a key role in the possible social acceptance of such a move, but it is a sign that gender norms are not static in
Kerala itself. Becoming oneself a nurse to go abroad may very well be a lesson learnt from the not so easy situation of older migrant nurses' husbands. In any case, in order to take the path of migration -the goal of so many young people in Kerala, both for economic and social reasons - some compromises have to be done with tradition. For young Christian men of middle-class or lower middle class background, it can be firstly a compromise with gender norms: the men I met in Ireland have to assume a new division of labor within their couple; for a new generation, it comes to assume a job for long considered as a purely women's job.

Marie Percot

Anthropoloque

Laboratoire d'Anthropologie

Urbaine/Institut Interdisciplinaire

d'Anthropologie du Contemporain

(EHESS/CNRS)

marie.percot@gmail.com

\section{Bibliography}

Boehm, Deborah A. (2004) Gender(ed) Migrations: Shifting Gender Subjectivities in a Transnational Mexican Community, University of California-San Diego La Jolla, Working Paper n¹00, 22 p.

Gallo, Ester (2006) Italy is not a good place for men: narratives of places and masculinity among Malayali migrants, Global Networks, nº, pp. 357-372.

George, Sheba M. (2005) When women come first. Gender and Class in Transnational Migration, Berkeley, University of California Press, 259 p. 
Humphries, Niamh (2008) Overseas nurse recruitment: Ireland as an illustration of the dynamic nature of nurse migration, Health Policy, Vol. 87, n², pp. 264-72.

Jeffrey, Robin (1993) Politics, Women and wellbeing, How Kerala became a model, New Delhi, Oxford University Press (Paperback), 285 p.

Kandel, W. ; Massey, D. S. (2002) The Culture of Mexican Migration: A Theoretical and Empirical Analysis, Social Forces, Vol. 80, n³, pp. 981-1004.

Monsutti, Alessandro (2005) La migration comme rite de passage : la construction de la masculinité parmi les jeunes Afghans en Iran, Cahiers Genre et Développement, n5, pp. 179-186.

Mathew, Liz (2006) Malayali nurses - lifeline of Keralites abroad, Gulf Times, Qatar, 26/9/2006. [en ligne, ref. du 21/02/11] URL :

<http://www.gulftimes.com/site/topics/art icle.asp?cu no $=2 \&$ item no $=109651 \& v e r s i o$ $\underline{n}=1$ \&template $\mathrm{id}=40$ \&parent $\mathrm{id}=22>$.

Mines, Richard (1981) Developing a Community Tradition of Migration: A Field Study in Rural Zacatecas, Mexico, and California Settlement Areas, San Diego La Jolla, University of California, Program in United States Mexican Studies, 219 p. (Monographs in U.S.-Mexican Studies, n ${ }^{\circ}$ ).
Nisbett, Nicholas (2009) Growing up in the Knowledge Society: Living the IT Dream in Bangalore, Delhi, Routledge, 220 p.

Osella, Caroline \& Osella, Filippo (2006) Men and masculinities in South India, London, Anthem Press, 241 p.

Percot, Marie (2006) Indian nurses in the Gulf: two generations of female migration, South Asia Research, Vol. 26, n¹, pp. 41-62.

Percot, Marie \& Naïr, Sreelekha (2010) Comment s'ouvrir les frontières du monde? La migration des infirmières indiennes, in Circulation et territoire dans le monde indien contemporain, Dupont, V. \& Landy, F. (eds.) Paris, EHESS, pp. 211-239.

Venier, Philippe (2011) Development of entrepreneurial initiatives in the UAE among Kerala emigrants, in Dynamics of Indian Migration: Historical and Current Perspectives, Rajan, I. \& Percot, M. (eds) New Delhi, Routledge, pp. 164-194.

Zachariah, K.C. \& Irudaya Rajan, S. (2004) Gulf Revisited, Trivandrum, Centre for Development Studies, Working paper n 363 , $89 \mathrm{p}$.

Zachariah, K.C.\& Irudaya Rajan, S. (2008) Kerala Migration Survey 2007, Trivandrum, Centre for Development Studies, 200 p. [en ligne, ref. du 24/09/11] URL: $<$ http://www.cds.edu/admin/homeFiles/K erala $\% 20$ Migration $\% 20$ Survey $\% 202007$.pdf $>$. 